\title{
Cikkismertetés: A keringési betegségek és halálozás módosítható kockázatai
}

\author{
Article review: Modifiable risks of cardiovascular diseases and mortality
}

Ismertető: $\quad$ Vitrai József $₫$

Ismertetett cikk: Yusuf S. et al. Modifiable risk factors, cardiovascular disease, and mortality in 155722 individuals from 21 high-income, middle-income, and low-income countries (PURE): a prospective cohort study. Lancet, 2020;395(10226):795-808. DOI: 10.1016/S01406736(19)32008-2

Beküldve: $\quad$ 2020. 03. 31.

doi: $\quad$ 10.24365/ef.v61i2.577

Kulcsszavak: keringési betegségek; halálozás; kockázat

Keywords: cardiovascular diseases; mortality; risk

\section{HÁTTÉR}

A szív- és érrendszeri betegségek és halálozás, valamint a módosítható kockázati tényezők közötti összefüggésre vonatkozó adatok nagyrészt eltérő módszertant alkalmazó vizsgálatokból származnak. A Prospective Urban Rural Epidemiology (PURE) kutatás viszont ugyanazon módszer alkalmazásával vizsgálja a módosítható kockázati tényezőknek a szív- és érrendszeri betegségek kialakulására és az amiatt bekövetkező halálozásra gyakorolt hatását öt kontinens 21 országában.

\section{MÓDSZEREK}

Ebben a követéses vizsgálatban 21 magas, közepes vagy alacsony jövedelmú országban vizsgálták meg 14 esetlegesen módosítható kockázati tényező hatását olyan résztvevők bevonásával, akiknek korábban nem volt szív- és érrendszeri betegsége. Az elemzés elsődleges eredménymutatója a szív- és érrendszeri betegségek fellépése illetve az a miatt bekövetkező halálozás volt. A vizsgálat során adatot gyűjtöttek a magatartási kockázatokról (mint pl. dohányzás, alkoholfogyasztás, étkezés, fizikai aktivitás és sóbevitel), élettani kockázatokról (mint pl. vérzsírszint, vérnyomás, cukorbetegség, elhízás), az egyének társadalmi-gazdasági és pszichoszociális kockázatokról (pl. iskolázottság, depresszió), valamint a beltéri és kültéri légszennyezettségről. Minden egyes kockázati tényezőre meghatározták, hogy a populációban észlelhető megbetegedésnek hány százaléka tulajdonítható az adott kockázati tényezőnek (populációs járulékos kockázati hányad; PJKH). A kockázati tényezők és az elsődleges eredménymutatók közötti összefüggéseket többváltozós statisztikai modellek alkalmazásával elemezték.

\section{EREDMÉNYEK}

A vizsgálatba 2005 januárja és 2016 decembere között 155722 résztvevőt vontak be és követtek. Közülük 11\% élt magas, $66 \%$ közepes és 23\% alacsony jövedelmú országban. Az eredmények alapján a szív és érrendszeri betegségek és 
halálesetek kb. 70\%-át módosítható kockázati tényezőknek tulajdonították. A betegségek kialakulását leginkább élettani kockázatokhoz lehetett kötni (PJKH: 41\%), ezek közül a magas vérnyomásnak volt a legnagyobb szerepe (PJKH: 22\%). A magatartási kockázatokat lehetett leginkább a halálozáshoz kapcsolni (PJKH: 26\%), bár önmagában a legnagyobb hatású kockázati tényező az alacsony iskolai végzettség volt (PJKH: 13\%). A kültéri légszennyezettséget a szív-érrendszeri betegségek 14\%-ával társították. A közepes és az alacsony jövedelemü országokban a beltéri légszennyezettség, a nem megfelelő étrend, az alacsony iskolai végzettség nagyobb hatással volt a szív-érrendszeri betegségekre vagy halálozásra, mint a magas jövedelmú országokban.

\section{KÖVETKEZTETÉSEK}

A legtöbb szív- és érrendszeri betegség kialakulása és az a miatt bekövetkezett halálozás nagy részéért csupán néhány módosítható kockázati tényező okolható. Míg egyes tényezők világszerte hatást mutatnak (pl. magas vérnyomás és iskolázottság), mások hatása (pl. a beltéri légszennyezettség és a rossz étrend) az országok jövedelmi szintjétől függően változnak. A kutatók szerint az egészségügyi szakpolitikáknak azokra a kockázati tényezőkre kellene összpontosítaniuk, amelyek az adott országban a legnagyobb szerepet játszhatják a szív- és érrendszeri betegségek, halálesetek megelőzésében.

\section{TANULSÁGOK A HAZAI SZAKEMBEREK SZÁMÁRA}

Mivel a szív- és érrendszeri betegségek túlnyomórészt módosítható kockázati tényezőkhöz köthetők, a hazai betegségterheket jelentősen csökkenteni lehetne néhány kockázati tényező visszaszorításával. Az egészséges életmód elterjesztése az élettani és a magatartási kockázati tényezők módosítása révén várhatóan igen komoly egészségnyereséggel járna Magyarországon. Emiatt célszerűnek látszik jóval több forrást biztosítani olyan népegészségügyi beavatkozásokra, amelyek az egészséges életmód előmozdítására és az azt támogató környezet kialakítására irányulnak. 